Arab Univ. J. Agric. Sci., Ain Shams Univ., Cairo, 14(2), 613-623, 2006

\title{
EVALUATION OF ORGANIC AND CHEMICAL FERTILIZERS EFFECT ON RHIZOSPHERE MICROFLORA AND POTATOES (SOLANUM TUBEROSUM.L) YIELD IN LOAMY SAND SOIL
}

[39]

\author{
Abo-Sedera ${ }^{1}$, S.A.
}

\begin{abstract}
A field experiment was carried out in a newly cultivated soil at Falouga, ElTahrir province, Behira governorate during the summer season (Spring plantation) of 2003 to investigate the effect of different organic manures (i.e. compost, F Y M or town refuse) each at rate of 20 ton/fed combined with the half recommended dose of mineral fertilizer (NPK) or 2 tons of chicken manure compared with the addition of the recommended dose of N P K at rate of 900, 400 and $200 \mathrm{Kg} / \mathrm{fed}$ ammonium sulphate, calcium superphosphate and potassium sulphate respectively. Application of organic manures, i.e. compost, FYM or town refuse each at the rate of 20 tons/fed combined with half amount of mineral fertilizer or 2 tons of chicken manure, increased total microbial count in soil at 60 days after planting compared to both uncultivated soil and chemical fertilized treatments. In this regard, the highest bacterial count was noticed in case of using FYM + chicken manure, while the highest count for total fungi and actinomycetes were recorded in the treatment of 20 tons compost + half amount of chemical fertilizer (NPK). In addition, using 20 ton compost +2 tons of chicken manures/fed, reflected the highest dry matter yield, total nitrogen, phosphorus and potassium content in plant foliage as well as total tuber yield of potatoes compared with other tested treatments.
\end{abstract}

Keywords: NPK, Compost, Farmyard manure, Town refuse, Chicken manure

\section{INTRODUCTION}

The addition of organic manures to the soil under favourable conditions resulted an increase in the number of various groups of soil microorganisms i.e. fungi, actinomycetes and bacteria. In this respect, Shady (1970), mentioned that the addition of organic matter to the soil of Kharga Oasis greatly stimulated the total microflora. Regarding the effect on soil properties, FAO (1977) reported that organic materials influenced the physical, chemical and biological characteristics of soil which in turn, influenced the development of plants. Omran (1979) men-

1- Agricultural Microbiology Dept., National Research Center, Cairo, Egypt

(Received April 6, 2006)

(Accepted May 6, 2006) 
tioned that numbers of bacteria and actinomycetes were increased in soil amended with different animal manures depending on the type of manure used as well as microorganisms under study. In addition, Hashem (1980) indicated that higher counts of bacteria and actinomycetes were detected when higher doses of organic matter were added to the soil. The densities of total bacteria were higher in calcareous than those in sandy soil, while the counts of actinomycetes were affected by time, type and amount of organic matter but not by the type of soil.

On the other hand, El-Huseiny et al (1984), concluded that organic manuring stimulated the proliferation of bacteria but the stimulation was more pronounced in sandy than in calcareous soil. ElHuseiny et al (1988) found that the application of organic manures as farmyard manure, town refuse, compost or sewage sludge at the rate of $2 \% \mathrm{w} / \mathrm{w}$ enhanced the total microbial flora. The sewage sludge was the most effective in this respect.

Potato (Solanum tuberosum L.) is one of the most important and favorite vegetable crops grown in Egypt. Fertilization either with mineral or organic fertilizers considered the most important agricultural practices, which affects the growing period of plant foliage and tuber formation as well as the quality of produced yield. In this regard, Abou-Hussein (1995); Abdel-Ati (1998); Arisha and Bardisi (1999) and Hassandokhat and Kashi (2000). Mentioned that application of organic manure either in the form of chicken manure or farmyard manure at different studied levels, affected greatly the vegetative growth, $\mathrm{K}$ content for plant foliage and produced tubers. As for the effect of nitrogen fertilization, many re- searchers found that nitrogen levels and frequent of application, affected significantly the vegetative growth of potato plants, [El-Gamal (1985a \& b); Arisha (1994) and Gabr et al (2001)], total tuber yield and its quality [Shehata \& AboSedera (1994); Joern \& Vitosh (1995), Kumar et al (1996); Belanger et al (2002); Singh et al (2002) and Bekhit et al (2005)]. The present study aims to investigate the effect of organic and chemical fertilizers mixtures on rhizosphere microflora and potatoes plant grown in loamy sand soil.

\section{MATERIAL AND METHODS}

\section{Experiment}

A field experiment was carried out in a newly cultivated loamy sand soil at $\mathrm{Fa}$ louga, El-Tahrir province, Behira governorate during the summer season (Spring plantation) of 2003, to investigate the effect of organic manures (i.e., compost, farmyard manure, chichen manure and town refuse) in addition to mineral fertilizers, on rhizosphere microflora as well as potato growth and tubers yield. According to Jackson (1958) the soil of the experimental field was loamy sand in texture with $\mathrm{pH}$ 7.8. Data of the physical and chemical analyses of the experimental field are shown in Table (1). A complete randomized block design with four replicates was adopted and the studied treatments were as follows

1- $900 \mathrm{~kg}$ ammonium sulphate $+400 \mathrm{~kg}$ superphosphate $+200 \mathrm{~kg}$ potassium sulfate/fed (control).

2- 20 tons compost $+1 / 2$ (N.P.K)/fed.

3- 20 tons farmyard manure $(\mathrm{FYM})+1 / 2$ (NPK)/fed. 
Table 1. Some physical, chemical and microbiological properties of the experimental soil

\begin{tabular}{|lc|}
\hline \multicolumn{2}{|c|}{ Soil properties } \\
\hline A. Physical \\
Sand \% \\
Clay \% & 87.39 \\
Silt \% & 11.36 \\
Soil texture & 1.25 \\
\hline B. Chemical & Loamy sand \\
Organic matter \% & \\
Total N \% & 18.0 \\
NH ${ }_{4} \mathrm{~N}$ mg Kg & .014 \\
NO ${ }_{3}$-N mg /Kg & 14 \\
P available mg/Kg & 8 \\
E.C (mmhos ) & 6 \\
PH & 1.03 \\
\hline C. Microbiological & $\mathrm{x} 10^{4}$ \\
Total bacterial count & 7.8 \\
Total fungal count & \\
Actinomycetes count & \\
\hline
\end{tabular}

4- 20 tons town refuse $+1 / 2$ (NPK) fed.

5- 20 tons compost +2 tons chicken manure/fed.

6- 20 tons (F.Y.M) + 2 tons chicken manure/fed.

7- 20 tons town refuse +2 tons chicken manure/fed.

The compost was prepared from sugar beet haulms by using highly effective cellulose decomposers, namely Streptomyces aureofaciens as described previously by Abo-Sedera (1995) and Badr EL-Din \& Abo-Sedera (2001). Farmyard manure used was a commercial available manure produced in special farm at Gharbia. Town refuse and chicken ma- nure were obtained, from Factory of town refuse compost at Gharbia Governorate. The chemical analysis of tested organic manure fertilizers was shown in Table (2). Potato tubers cv. Alpha were planted on February $23^{\text {rd }} 2003$. The area of the experimental plot was $45 \mathrm{~m}^{2}$, it included three rows each $20 \mathrm{~m}$ length and $75 \mathrm{~cm}$ width. Organic manures and half of superphosphate amounts were added at soil preparation. The second half of superphosphate fertilizer was added with nitrogenous and potassium fertilizers. It was added in three equal doses at complete germination and every two weeks intervals. Other agricultural practices 
Abo-Sedera

Table 2. Some chemical analyses of organic manures

\begin{tabular}{|lcccc|}
\hline Constituents \% & Compost & F.Y.M & Town refuse & Chicken manure \\
\hline Organic matter & 26.20 & 16.20 & 22.4 & 67.10 \\
Organic C & 15.20 & 9.40 & 13.0 & 38.90 \\
Total N & 1.20 & 0.48 & 1.10 & 3.50 \\
Total P & 1.10 & 0.52 & 1.10 & 1.30 \\
Total K & 0.90 & 0.72 & 0.90 & 3.10 \\
C/N ratio & 12.66 & 19.58 & 11.8 & 11.11 \\
\hline
\end{tabular}

required for potato production, were carried out as commonly followed in the district.

\section{Microbiological analysis}

Microbiological analysis in the rhizosphere samples was estimated according to the technique described by Louw and Webley (1959). At the start of the flowering stage i.e. after 60 days from sowing, a random samples consisted of 5 plants were collected from each plot and divided into roots and foliage parts. The roots were gently shaked to remove adhering loosely soil particles and were used for estimation of rhizosphere micro flora, in potato rhizosphere. The serial dilution plate method was used for counting total bacteria on modified soil extract yeast agar medium (Mahmoud et al 1964), fungi on Martin medium (Allen, 1966) and actinomycetes on glucose asparagine agar medium (Szabo 1974).

\section{Agronomic Parameters}

\section{Dry matter yield}

The foliage parts of the random 5 plants sample, were oven dried for determination of the dry matter yield.

\section{Chemical analysis}

Organic matter content of organic manures was determined by ignition in a muffle furnace at $550 \mathrm{C}^{\mathrm{o}}$ for $5 \mathrm{~h}$. Total nitrogen, phosphorus and potassium contents in plant foliage were assayed according to the methods described by Hesse (1971); Murphy and Riely (1962) and Brown and Lilleland (1946) for N, $\mathrm{P}$ and $\mathrm{K}$, respectively.

\section{Tuber fresh yield}

At harvest (120 days after planting) all plants in each experimental plot were pulled and tubers were collected and weighed to calculate total tuber yield /Feddan. 
All the collected data were subjected to statistical analysis according to Gomez and Gomez (1984).

\section{RESULTS AND DISCUSSION}

\section{Microbiological counts}

It is of interest to mention that the microbial densities in the experimental soil before planting were $140.1 ; 2.1$ and $1.1 \times 10^{4}$ for total bacteria; total fungi and total actinomycetes respectively (Table 1). Data presented in Table (3) show the effect of mineral fertilizer (NPKI) and different organic manures (i.e., compost, farmyard manure and chicken manure) on total microbial count at 60 days after sowing. Such data reveal that application of organic manures either in combination with 2 tons chicken manure or with half amount of mineral fertilizer, stimulated the growth of soil microorganisms and increased their counts in the rhizosphere compared with using mineral fertilizer alone (check treatment). In this respect, the highest total bacterial count was noticed in case of FYM + chicken manure application, meanwhile, the highest count for total fungi and actinomycetes were recorded in case of the application of compost manure combined with half of the amounts of mineral fertilizer. Such inhaling effect of organic fertilizers especially Farmyard manure and compost on growth and number of microorganism was also reported by Mahamoud $\boldsymbol{e t}$ al (1964), Hashem (1980) El-Huseiney et al (1984) Neweigy et al (1984) and ElHuseiney et al (1988). They reported that both farmyard manure and town refuse compost stimulated the growth of soil microorganism, and increased their count progressively after application.

\section{Plant Growth}

Data recorded in Table (4) show the effect of mineral and organic manure fertilizers application on growth of potato plants expressed as dry weight of plant foliage. In this regard, application of organic manure mixture i.e., compost + chicken manure, farmyard + chicken manure and town refuse + chicken manure significantly increased the dry weight of plant foliage compared with application of mineral fertilizer (NPK) in a single form or organic fertilizer amount combined with half rate of mineral fertilizer.

In this respect, the highest value of dry matter content for plant foliage was obtained as a result of using chicken manure at a rate of 2 tons/fed combined with either 20 tons compost or 20 tons farmyard manure/fed. Increasing plant dry weight as the result of the application of organic fertilizer may be due to the main role of such organic manure on improving physical and biological conditions of sandy soil as well as their role as a source for macro and micro-nutrients, which in turn increase plant growth. As well as the increase in plant foliage yield could be attributed to the increasing activity of rhizosphere microflora which was enhanced by the application of different organic manures. In this concern, AbouHussein (1995) Abdel-Ati (1998) Arisha and Bardisi (1999) Hassandokht and Kashi (2000) and Bekhit et al (2005) mentioned that application of organic manure either in the form of chicken manure or farm yard manure at different studied levels, affected greatly the vegetative growth for plant foliage. 
Table 3. Effect of different organic manures on total bacterial, actinomycetes and total fungal counts $\left(\mathrm{x} 0^{5}\right)$ in rhizosphere of potato plants after 60 day s of sowing

\begin{tabular}{|lccc|}
\hline \multicolumn{1}{|c}{ Treatment } & $\begin{array}{c}\text { Total } \\
\text { count }\end{array}$ & $\begin{array}{c}\text { Total } \\
\text { fungi }\end{array}$ & Actinomycetes \\
\hline N P K & 160. & 2.5 & 1.8 \\
$\mathbf{2 0}$ tons Compost+1/2 NPK & 326. & 8.5 & 9.5 \\
$\mathbf{2 0}$ tons Tons Farmyard +1/2 NPK & 352. & 7.9 & 8.9 \\
$\mathbf{2 0}$ tons Town refuse + 1/2 NPK & 310. & 6.7 & 8.7 \\
$\mathbf{2 0}$ tons Compost + 2 tons Chicken & 365. & 7.3 & 6.9 \\
$\mathbf{2 0}$ tons FYM + 2 tons Chick manure & 386. & 6.9 & 6.4 \\
$\mathbf{2 0}$ tons Town refuse +2 tons Chicken & 356. & 7.6 & 6.7 \\
\hline
\end{tabular}

Table 4. Effect of different fertilizers on dry weight of plant foliage and its nutrients content as a percentages and $\mathrm{mg} / \mathrm{plant}$ (after 60 days of sowing)

\begin{tabular}{|c|c|c|c|c|c|c|c|}
\hline \multirow[b]{2}{*}{ Treatments } & \multirow{2}{*}{$\begin{array}{c}\text { Dry } \\
\text { weight } \\
\text { g/plant }\end{array}$} & \multicolumn{2}{|c|}{$\mathbf{N}$} & \multicolumn{2}{|c|}{$\mathbf{P}$} & \multicolumn{2}{|c|}{$\mathbf{K}$} \\
\hline & & $\mathbf{N \%}$ & $\begin{array}{c}\text { mg/ } \\
\text { plant }\end{array}$ & $\mathbf{P} \%$ & $\begin{array}{c}\text { mg/ } \\
\text { plant }\end{array}$ & $\mathbf{K} \%$ & $\begin{array}{l}\text { mg/ } \\
\text { plant }\end{array}$ \\
\hline N.P.K & 12.63 & 1.22 & 154 & 0.165 & 20.38 & 1.62 & 205 \\
\hline 20 tons compost $+1 / 2$ NPK & 17.6 & 1.24 & 291 & 0.17 & 30.25 & 1.42 & 253 \\
\hline 20 tons FYM +1/2 NPK & 17.27 & 1.18 & 204 & 0.16 & 27.63 & 1.48 & 256 \\
\hline 20 tons Town refuse $+1 / 2$ NPK & 16.70 & 1.18 & 197 & 0.17 & 28.40 & 1.49 & 249 \\
\hline $\begin{array}{l}20 \text { tons compost }+2 \text { ton chicken } \\
\text { manure }\end{array}$ & 18.77 & 1.18 & 221 & 0.18 & 33.75 & 1.40 & 263 \\
\hline $\begin{array}{l}20 \text { tons FYM }+2 \text { ton chicken } \\
\text { manure }\end{array}$ & 18.10 & 1.20 & 217 & 0.17 & 30.77 & 1.42 & 254 \\
\hline $\begin{array}{l}20 \text { tons Town refuse }+2 \text { ton } \\
\text { chicken manure }\end{array}$ & 17.92 & 1.18 & 211 & 0.16 & 28.67 & 1.45 & 260 \\
\hline L.S.D at 0.05 & 1.01 & N.S & 11.7 & N.S & 2.43 & 0.10 & 12 \\
\hline
\end{tabular}

N.S. : insignificant differences 


\section{Chemical composition of plant foliage}

Data presented in Table (4) show that nitrogen percentages in plant foliage were not affected due to application of the tested organic fertilizers. On the other hand, nitrogen uptake as $\mathrm{mg} / \mathrm{plant}$ showed highly significant differences due to the applied treatments. The highest amount of $\mathrm{N}$ - uptake was recorded in the treatment received 20 tons compost in combination with half dose of mineral fertilizer. In this regard, organic manuring in combination with mineral fertilizer increased $\mathrm{N}$ - uptake compared to mineral fertilizers only. With regard to phosphorus percentages in plant foliage, no significant differences were noticed due to the different treatments, while P-uptake showed significant differences between the treatments. The highest P-uptake was recorded in treatment of 20 tons compost in combination with 2 tons chicken manure. The same trend was recorded in $\mathrm{K}$ uptake. The stimulative effect of compost on plant uptake of the studied nutrients could be attributed to the microbial populations content in the compost compared to other manures.

Such increment in total N, P and K uptake due to the application of the studied organic fertilizers, compared to mineral fertilizer could be attributed to the slow release of available amount of such macro-nutrients in root zone due to the increasing activity of the microbial population in such sandy soil, which stimulates the plant absorption of such nutrients and hence increases their content in plant foliage. Obtained results are in the same line with those reported by $\mathbf{A b}$ del-Ati (1998); Arisha and Bardisi (1999); Nadia et al (2000); Gabr et al (2001) and Bekhit et al (2005) on potato, who found that increasing the used levels of fertilizer, significantly increased N, P and $\mathrm{K}$ content in plant foliage.

\section{Total tuber yield}

Data recorded in Table (5) show the effect of organic manures and mineral fertilizers on total tuber yield per fed. From such data it is clear that using organic fertilizers as compost, FYM or town refuse either combined with half of recommend rate of NPK or with 2 tons of chicken manure, significantly increased the produced tuber yield /fed, compared with using mineral fertilizer alone (NPK). In this regard, application of 20 tons compost combined with 2 tons chicken manure instead of using half of the amount of chemical fertilizer, reflected the highest value of total tuber yield compared with using the full dose of NPK chemical fertilizer, or 20 tons of other tested organic manure +2 tons of chicken manure, or plus the half dose of NPK fertilizer. Such significant increase in tuber yield due to addition of compost + chicken manure may be due to the high quality of compost and its role in biological control of soil born disease (Badr Eldin and Abo Sedera 2001), in addition may be due to the role of organic fertilizers as amendement for improving physical and chemical characteristics of the soil, which in turn was reflected on plant growth (Table 4) and tuber yield (Table 5). Obtained results are in agreement with those indicated by Abou-Hussein (1995) Roy and Jaiswal (1998) Singh et al (2002) and Bekhit et al (2005), all working on potatoes and reported that total yield of potato was increased with the highest used level of cattle manure combined with chicken manure or nitrogen fertilizer. 
Table 5. Effect of mineral fertilizers and different organic manures on potato tubers yield (tons /fed).

\begin{tabular}{|lc|}
\hline \multicolumn{1}{|c|}{ Treatments } & Tons /fed \\
\hline NPK & 10.400 \\
20 tons compost +1/2 NPK & 16.800 \\
$\mathbf{2 0}$ tons FYM + 1/2 NPK & 14.800 \\
20 tons Town refuse $+\mathbf{1 / 2}$ & 14.500 \\
NPK & \\
20 tons compost $+\mathbf{2}$ ton & 16.300 \\
chicken manure & \\
$\mathbf{2 0}$ tons FYM $+\mathbf{2}$ ton chicken & 15.200 \\
manure & \\
$\mathbf{2 0}$ tons town refuse $+\mathbf{2}$ ton & 15.100 \\
chicken manure & \\
L.S.D at 0.05 & 0.870 \\
\hline
\end{tabular}

\section{REFRENCES}

Abdel-Ati, Y.Y. (1998). Yield and quality of potato as affected by phosphorus, chicken manur and seed tuber size. Assiut J. Agric. Sci. 29(5): 129-147.

Abo-Sedera, S.A. (1995). Biological and Chemical Studies on Organic Wastes Decomposition. p. 103. Ph.D, Thesis. Faculty of Agric., Al-Azhar University, Cairo, Egypt.

Abou-Hussein, S.D. (1995). Studies on Potato Fertigation in Newly Reclaimed Land. p. 93. M.Sc. Thesis, Fac. Agric., Ain Shams Univ., Cairo, Egypt

Allen, O.N. (1966). Experiments in Soil Bacteriology. Burgess Publ., Co., mineapolis, U.S.A. p. 66.

Arisha, H.M.E. (1994). Effect of nitrogen fertilizer level and frequent of application on growth, yield and tuber quality of potato under reclaimed soil. Zagazig $\mathbf{J}$. Agric. Res., 21(3): 925-934. Egypt

Arisha. H. and A. Bardisi (1999). Effect of mineral and organic fertilizers on growth, yield and tuber quality of potato under sandy soil conditions. Zagazig. J. Agric. Res., 36(1): 391-409. Egypt

Badr El-Din, S.M.S. and S.A. AboSedera (2001). Acceleration of composting of sugar beet haulms using two highly effective cellulose decomposing microorganisms. Egyptian J. Microbiol., 36: 161-174.

Bekhit, R.S.; H.H. Hassan; H.M. Ramadan and A.M.A. Al-Anany (2005). Effect of different levels and sources of nitrogen on growth, yield and quality of potatoes grown under sandy soil conditions. Annals of Agric. Sci., Moshtohor, 43(1): 381-394. Egypt

Belanger, G.; J.R. Walsh; J.E. Richads; P.H. Milburn and N. Ziadi (2002). Nitrogen fertilization and irrigation effects on tuber characteristics of two potato cultivars. Amer. J. Potato Res., 79: 269-279.

Brown, G.D. and O.L. Lilleland (1946). Rapid determination of potassium and sodium in plant material and soil extract by flame photometry. Proc. Amer. Soc. Hort. Sci., 48: 341-346.

El-Banna, E.N. and H.Z. Abd El-Salam (2000). Effect of rock phosphate and superphosphate application with organic manures on growth, yield and quality of potato (Solanum tuberosum L.). J. Agric. Sci. Mansoura Univ., 25(7): 4531-4540. Egypt

El-Huseiny, T.M.; N.A. Neweigy; Ehsan A. Hanafy and Nadia, I.M. Abd ElHady (1984). The effect of chemical and bacteriological transformation of organic materials on the availability of some nutrient elements in sandy and calcareous 
soils. Annals of Agric. Sci., Moshtohar, 22: 201-220. Egypt.

El-Huseiny, T.M.; M.K. Sadik; R.S. Abdel-Aal and Nadia, M. Badran (1988). Biological degradation of different organic manures in Egyptian soil and their effect on soil microorganisms. Egypt. J. Microbiol., 23: 209-221.

El-Gamal, A.M. (1985a). Effect of four nitrogen sources on potato production and quality. J. Agric. Sci., Mansoura Univ., 10(4): 1454-1458.

El-Gamal, A.M. (1985b). Effect of level and number of application of nitrogen on potato yield and quality. J. Agric. Sci., Mansoura Univ., 10(4): 1459-1463. Egypt .

FAO Soils Bulletin., (1977). China : recycling of organic wastes in agriculture. FAO Soils Bull. No 40, Rome.

Gabr, S.M.; I.M. Ghoneim and F.H. Mohamed (2001). Effects of nitrogen levels and nitrate ammonium ratios on growth, yield and chemical composition of potato. Adv. Agric. Res., 6(4): 922937.

Gomez, K.A. and A.A. Gomez (1984). Statistical Procedures for Agric. Res. $2^{\text {nd }}$ Ed. pp. 139-153. Wiley \& Sons, Pub., N.Y.

Hashem, Farh. A. (1980). Studies on the Activities of Microorganisms in Desert Soils and Their Relation to Soil Fertility. pp. 85. M.Sc. Thesis, Fac. Agric., Zagazig Univ. Egypt.

Hassandokht, M.R. and A. Kashi (2000). Effect of farmyard manure and nitrogen application on the quantity and quality of potato crop. Seed and Plant, 15: 323-330.

Hesse, P.R. (1971). A Text Book of Soil Chemical Analysis. pp. 75-80. Jhon Murray (Pub.), London.
Jackson, M.L. (1958). Soil Chemical Analysis, pp. 183-203. Constable and Co. Ltd., London.

Joern, B.C. and M.L. Vitosh (1995). Influence of applied nitrogen on potato. Part 1: yield, quality and nitrogen uptake. Amer. Potato J. 72: 51-63.

Kumar, B.; Jitendra-Kumar; S.S. Singh; M.V. Singh and J. Kumar (1996). Response of potato variety Kufri Lalima to nitrogen fertilization under eastern Utter Pradesh conditions. New Agriculturist, 7(1): 11-15.

Louw, H.A. and W. Webley (1959). The bacteriology. of the root region of the oat plants grown under controlled pot culture conditions. J. Appl. Bacteriol, 12: 216220.

Mahmoud, S.A.; M. Abou El-Fadl and M.K.H. El-Mofty (1964). Studies on the rhizosphere microflora of a desert plant, Folia Microbiogica, 9: 1-6.

Murphy, J. and J.P. Riely, (1962). A modified single solution method for determination of phosphate in natural waters. Anal. Chem. Acta, 97: 31-36.

Nadia, M. Badran; M.E.A. Khalil and M.A.A. El-Emam (2000). Availability of $\mathrm{N}, \mathrm{P}$ and $\mathrm{K}$ in Sandy and clayey soil as affected by the addition of organic materials. Egypt. J. Soil Sci., 40: 265-283.

Neweigy, N.A.; T.M. El-Huseiny; Ehsan A. Hanafy and Nadia, I.M. Abd-ElHady, (1984). Influence of organic matter addition on microbiological activation on calcareous and sandy soils in Egypt, Annals of Agric. Sci., Moshtohor, 22: 223-235. Egypt.

Omran, A.A.M. (1979). Comparative Studies on The effect of Local Organic Manures on Certain Soil Microorganisms. p. 85. M.Sc. Thesis, Fac. Agric., ElMinia Univ., Egypt. 
Roy, S.K. and V.P. Jaiswal. (1998). Response of potato (Solanum tuberosum) to planting dates and nitrogen. Indian $\mathbf{J}$. of Agronomy. 43: 484-488.

Shady, M.A.M. (1970). Microbiological Studies on Kharga Oasis Soils. p. 166. M. Sc. Thesis, Fac. Agric., Cairo Univ. Egypt.

Shehata, S.A. and F.A. Abo-Sedera. (1994). Effect of irrigation frequency and NK level on growth, yield, chemical composition and storage ability of potatoes. Zagazig J. Agric. Res., 21(1): 129. 143.
Singh, N.; M.C. Sood; R.C. Sharma; S.M.P. Khurana; G.S. Shekhawat; S.K. Pandey and B.P. Singh (2002). Effect of irrigation levels, cultural practices and nitrogen application on potato production under drip and sprinkler methods of irrigation. Proceedings of the GlobalConference on Potato, New Delhi, India -Volume 2: 923-925.

Szabo, I.M. (1974). Microbial communities in a Forest Rendzina Ecosystem. Akademiai Kiado, Budapest In: Cellulose Decomposition and Soil Fertility. p. 44, 1988. J. Szegi, ed., Akademiai Kiado, Budapest.

\section{بحلة اتحاد الجامعات العربية للدراسات والبحوث الزراعية ، جامعة عين شمس ، القاهرة ،14(2) ، 613-623 ، 2006 تقيمث أثز الاسمده العضوية والكيماوية على ميكرويات منطقة الريزوسفيز ومحصول البطاطس في الاراضي الطمية الرملية}

$$
\begin{aligned}
& \text { صلاح أبو النصر أبو سديرة } \\
& \text { 1- قم الميكروبيولوجيا الزراعية - المركز القومى للبحوث - الاقى -القاهرة- مصر } \\
& \text { مقارنة بالمع دل الموصسى بة من الاسمده } \\
& \text { أجريت تجربة حقليه فى تربة طميية }
\end{aligned}
$$

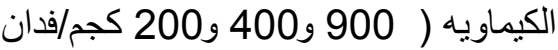

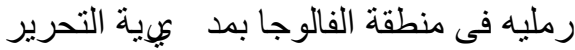

$$
\begin{aligned}
& \text { كبريتات امونيوم وسوبرفوسفات الكالسوم } \\
& \text { بمحافظة البحيرة على محصول البطاطس مله } \\
& \text { وكبريتات بوتاسيوم على التوالى) . } \\
& \text { وصممت التجربه بنظام القطاعات تامة } \\
& \text { (صنف الفا) ، و استخدم فيها اسمده عضويه } \\
& \text { مختلفه ، هى السماد العضوى الصناعى ، والعى } \\
& \text { العشو ائيه و اشتملت على اربعة مكرر ات وتم } \\
& \text { المحضر من عرش نبات بنجر السكر }
\end{aligned}
$$

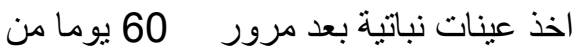

$$
\begin{aligned}
& \text { تاريخ الزر اعة ، وذللك لتقدير اعداد } \\
& \text { و السماد البلدى وسماد القمامه بمعدل } 20 \text { طن عن لفن } \\
& \text { الميكروبات في منطقة الجذور ، وكذللك تقدير } \\
& \text { /فدان مضافا اليها سماد زرق الدو اجن بمعدل } \\
& \text { 2طن /فدان اونصف الاسمده الكيماويه }
\end{aligned}
$$




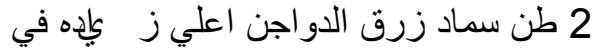
الاعداد الكلية للبكتريا ، كما كانت أعلي زيادة اعلي

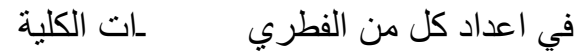

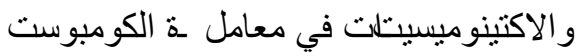

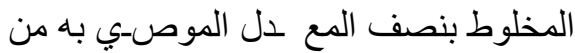

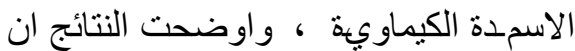

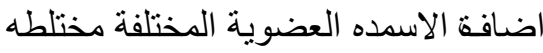

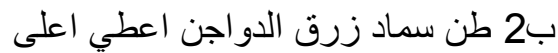

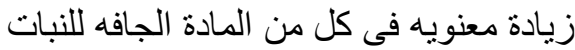
ومعدل امتصاص النبات للعناصر الغذائية ومحصول درنات البطاطس عن (N, P, K)

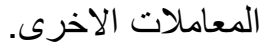

المادة الجافه و التحليل الكيماوى لكل من

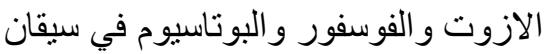
واوراق النبات ، كما تم تقدير محصول درنات البطاطس لكل معاملة فى نهاية التجربة(120 يومات النطاطية)

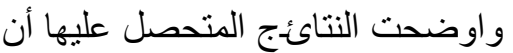
التسميد بالاسمدة العضوية المختلفه ـ السماد

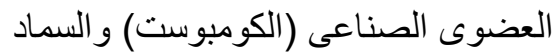

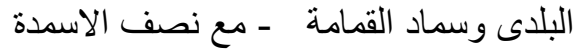
الكيماوية ادي الى زيادة اعداد الميكروبات الكلية في منطقة الجذور بالمقارنة بالتربة الكباد المبكروبات

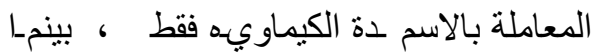

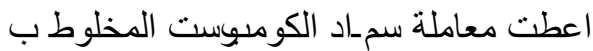

تحكيم: أ.د السيد أحمد صالح

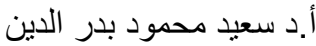

